\title{
Effects of Natural and Synthetic Soil Conditioners on Soil Moisture Retention and Maize Yield
}

\author{
M. Yangyuoru ${ }^{1 *}$, E. Boateng ${ }^{2}$, S.G.K. Adiku ${ }^{3}$, D. Acquah ${ }^{1}$, T.A. Adjadeh ${ }^{3}$, and F. Mawunya ${ }^{1}$ \\ ${ }^{1}$ College of Agriculture \& Consumer Sciences, Agricultural Research Centre, Kpong, \\ University of Ghana, Legon-Accra, Ghana \\ 2 Soil Research Institute, Council for Scientific and Industrial Research (CSIR), P. O. \\ Accra, Ghana \\ ${ }^{3}$ College of Agriculture \& Consumer Sciences, Department of Soil Science, P. O. \\ 245, University of Ghana, Legon-Accra, Ghana \\ * Corresponding author, E-mail: macariusy@hotmail.com
}

P. O. Box 68,

Box M. 32,

Box

\begin{abstract}
The efficacy of a natural soil conditioner, Coco-Peat (C-P), and synthetic soil conditioners, Terawet (T-200) and Teraflow (T-F), in improving soil moisture content were examined on five Ghanaian soil series (Akroso, Akuse, Amo, Hake and Oyarifa). In general, the water retention of T-200 and C-P treated soils were similar but significantly higher $(\mathrm{p}<0.001)$ than that of T-F and the control $(\mathrm{C}-\mathrm{T})$

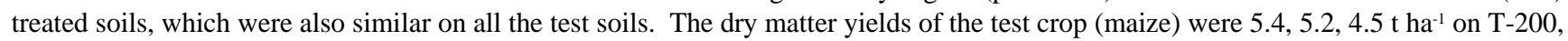
C-P and T-F treated soils, respectively, on Akroso series. These yields were 36\%, 31\% and 5\%, respectively, more than those of the control treatment. On Akuse series even though T-200 and T-F gave higher dry matter yields than the control, the differences were not significant, only C-P treatment gave significantly higher $(\mathrm{p}<0.001)$ yield than the control. On Amo series, dry matter yields of $6.1,5.8$ and $4.9 \mathrm{t} \mathrm{ha}^{-1}$ on T-200, C-P and T-F treated soils, respectively, were 38\%, 31\% and 10\% more than the control treatment. On Hake series, T-200, C-P and T-F treatments improved dry matter yields by $45 \%, 32 \%$ and $12 \%$, respectively, over that of the control. The greatest effect of the polymeric absorbents was observed on the sandy/clay/loam Oyarifa series. The treatments T-200, C-P and T-F improved dry matter yields by $92 \%, 81 \%$ and $4 \%$, respectively, over the control treatment. The results indicate that the differences in yields over the control were due to the improved water retention ability of the soils amended with the polymeric absorbents.
\end{abstract}

\section{Introduction}

Efficient management of soil moisture is important for agricultural production in the light of scarce water resources. Soil conditioners, both natural and synthetic, contribute significantly to provide a reservoir of soil water to plants on demand in the upper layers of the soil where the root systems normally develop. These polymeric organic materials and hydrogels apart from improving the soil physical properties, also serve as buffers against temporary drought stress and reduce the risk of plant failure during establishment (De Boodt, 1990; Johnson \& Leah, 1990). This is achieved by means of reduction of evaporation through restricted movement of water from the sub-surface to the surface layer (Ouchi et al., 1990).

The decomposition of organic polymeric products in soil by microbial activities results in compounds such as polysaccharides and polyuronides (Hillel, 1980). These promote soil aggregate stability by gluing particles together within aggregates, as well as coating aggregate surfaces. One of the recently developed organic soil conditioners, Coco-Peat, has been observed to greatly improve the physical and chemical status of soils (Managecraft, 2001). Coco-Peat is a finely processed coconut husk, produced from the inner fibers, pith and organic grits, and this accounts for its high moisture retention characteristics. The short life span of organic soil conditioners has led to increase interest in synthetic soil conditioners.

The influence of synthetic soil conditioners on the growth of plants have, so far, been investigated using linearly polymerized polyacrylamides that have, rather, low content of carboxylic groups (De Boodt, 1975; Azzam, 1980; Wallace \& Nelson, 1986). New generations of soil conditioners are highly cross-linked polyacrylamides with $40 \%$ of the amides hydrolyzed to carboxylic groups. These polymers do not interact directly with the soil matrices but form aqueous gels and act as water reservoirs for the plant-soil system. The roots of the plant grow through the matrix of these hydro-gelled particles and draw water from them when required. Quchi et al. (1989) and Bouranis et al. (1995) have shown that water held by potassium-based polymer is completely available to plants. Sodium-based polymers are observed to have lower hydration capacity compared to that of potassium-based polymers (Bowman et al. 1990). 


\section{West Africa Journal of Applied Ecology (WAJAE) -ISSN: 0855-4307 \\ Volume 9 (Jan - Jun 2006) \\ www.wajae.org}

The introduction of potassium-based copolymers, Terawet (T-200) dramatically increased the water retention capacity of the soil by 400 times its weight and absorbs it faster than all its predecessors. Unlike previous polymeric absorbents, these crystals are able to retain moisture under soil pressure or in the presence of other water-soluble additives. Dehgan et al. (1994) showed that amending the growth medium with $0.75 \%$ by volume of potassium-based Terawet super-absorbent polymer resulted in application of $50 \%$ less irrigation water. The utilization of synthetic polymers resulted in increased tissue nutrients levels concomitant with reduced leaching of some nutrients and runoff (Dehgan et al., 1994; Sweet, 1994). Teraflow, a unique liquid polymeric formulation, also from Terawet Corporation, has similar water absorption capabilities as Terawet. The synthetic product consists of liquid acrylamide copolymer of surfactants, micronutrients, sulfates and sodium asrylate. Teraflow encapsulates water molecules and holds water in the root zone for long periods of time before leaching away.

This pioneering work examines the effects of a natural soil conditioner, Coco-Peat (C-P), a synthetic crystal polymer Terawet (T-200) and a liquid synthetic formulation Teraflow (T-F), on five Ghanaian soil series. The study aims to evaluate the efficacy of the polymeric soil conditioners based on their soil water retention and their effects on the growth performance of maize.

\section{Materials and methods}

The experiment was conducted at the University of Ghana Agricultural Research Centre (ARC), Kpong, at an altitude of $18 \mathrm{~m}$ above sea level. The mean air temperature is $27.2^{\circ} \mathrm{C}$, with mean maximum and minimum temperatures of $33.3{ }^{\circ} \mathrm{C}$ and $22.1{ }^{\circ} \mathrm{C}$, respectively. The relative humidity for the night time to the early hours of the day ranges from 70 to $100 \%$ throughout the year. The afternoon relative humidity falls to a range of 20 $65 \%$ during the year.

The field investigation was a $4 \times 5$ factorial pot-experiment with maize as the test crop. A randomised split-plot design was used with four replications. The main plot treatment was soil type and comprised five different Ghanaian soil series. Samples of four of these soil types; Akuse, Amo, Hake and Oyarifa, were collected from the coastal savanna zone and the fifth one, Akroso, is from the forest zone. The general description and classification of these soils are given in Table 1 . The subplot treatment was polymeric absorbents consisting of four different types: Coco-Peat (an organic polymeric absorbent), Terawet and Teraflow (both synthetic polymeric absorbents) and the control (soil with no absorbents). The general composition and description of the polymeric absorbents are presented in Table 2.

TABLE 1

General description of the selected soils

\begin{tabular}{|c|c|c|c|c|c|}
\hline $\begin{array}{l}\text { Soil } \\
\text { series }\end{array}$ & $\begin{array}{l}\text { Classification } \\
(F A O, 1990 \& \\
\text { USDA*) }\end{array}$ & Parent materials & Vegetation & Topo-site & Texture \\
\hline Akroso & $\begin{array}{l}\text { Haplic Acrisol } \\
\text { (Typic Hapludult) }\end{array}$ & Biotite granite & Forest & Middle slope & $\begin{array}{l}\text { Silty clay loam } \\
\text { or silty loam }\end{array}$ \\
\hline Akuse & $\begin{array}{l}\text { Calcic Vertisol } \\
\text { (Typic Calciustert) }\end{array}$ & $\begin{array}{l}\text { Garnetiferous } \\
\text { hornblende gneiss }\end{array}$ & Coastal savanna & $\begin{array}{l}\text { Upper-middle } \\
\text { slope }\end{array}$ & $\begin{array}{l}\text { Sandy to silty } \\
\text { clay }\end{array}$ \\
\hline Amo & $\begin{array}{l}\text { Gleyic Cambisol } \\
\text { (Vertic Endoaquept) }\end{array}$ & Recent alluvium & Coastal savanna & Lower slope & Silty clay \\
\hline Hake & $\begin{array}{l}\text { Eutric Cambisol } \\
\text { (Typic Eutrochrept) }\end{array}$ & Old alluvium & Coastal savanna & Middle slope & Silty light clay \\
\hline Oyarifa & $\begin{array}{l}\text { Haplic Lixisols } \\
\text { (Typic Rhodudalf) }\end{array}$ & $\begin{array}{l}\text { Feruginous } \\
\text { colluvium, } \\
\text { sandstone, } \\
\text { quartzites }\end{array}$ & $\begin{array}{l}\text { Coastal savanna } \\
\text { slope }\end{array}$ & $\begin{array}{l}\text { Mid-piedmont } \\
\text { loam }\end{array}$ & Sandy clay \\
\hline
\end{tabular}




\section{West Africa Journal of Applied Ecology (WAJAE) -ISSN: 0855-4307 \\ Volume 9 (Jan - Jun 2006) \\ www.wajae.org}

*USDA Classification in parenthesis

TABLE 2

General description of the polymeric absorbents

\begin{tabular}{|c|c|c|c|}
\hline Name & Terawet (T-200) & Teraflow $(T-F)$ & Coco-Peat (C-P) \\
\hline $\begin{array}{l}\text { Composition or } \\
\text { active } \\
\text { ingredients }\end{array}$ & $\begin{array}{l}\text { Highly cross linked } \\
\text { polyacrylate-polyacrylamide } \\
\text { copolymer } \\
\text { potassium based }\end{array}$ & $\begin{array}{l}\text { Acrylamide copolymer } \\
\text { of surfactants, micro- } \\
\text { nutrients, Sulfates } \\
\text { and sodium asrylate }\end{array}$ & $\begin{array}{l}\text { Ground coconut husk fibres, } \\
\text { pith organic grit and many } \\
\text { natural nutrients }\end{array}$ \\
\hline Appearance & $\begin{array}{l}\text { White granular crystals of size } \\
\text { 2000-3000 microns }\end{array}$ & Liquid, clear to amber & $\begin{array}{l}\text { Organic grits, } 100 \% \text { organic } \\
\text { medium }\end{array}$ \\
\hline $\begin{array}{l}\text { Application rate } \\
\text { for potted plants }\end{array}$ & $2.67 \times 10^{4} \mathrm{~kg} \mathrm{ha}^{-1} \mathrm{~m}^{-1}$ & 45.5 litres ha $^{-1}$ & $\begin{array}{l}\text { Application ratio of } \\
\text { C-P: Soil is } 1: 4\end{array}$ \\
\hline $\begin{array}{l}\text { Mode of } \\
\text { application }\end{array}$ & $\begin{array}{l}\text { Mixed with soil below the } \\
\text { surface at the root zone of } \\
\text { the crop }\end{array}$ & $\begin{array}{l}\text { Surface spray by hose, } \\
\text { drip irrigation, overhead } \\
\text { and pivot sprinklers }\end{array}$ & $\begin{array}{l}\text { Spread } 13 \mathrm{~mm} \text { over the soil } \\
\left(10 \text { litres } / \mathrm{m}^{2}\right) \text { then dig or rake } \\
\text { into soil }\end{array}$ \\
\hline $\begin{array}{l}\text { Solubility in } \\
\text { water }\end{array}$ & Insoluble & Infinite & $\begin{array}{l}\text { Slowly soluble on } \\
\text { decomposition }\end{array}$ \\
\hline Odour & No odour & Non to mild citrus odour & $\begin{array}{l}\text { Pungent scent on } \\
\text { decomposition }\end{array}$ \\
\hline Longevity & $\begin{array}{l}\text { Stable for more than } 7 \text { years } \\
\text { application }\end{array}$ & $\begin{array}{l}\text { Stable for more than } 7 \\
\text { years after a single } \\
\text { after a single application }\end{array}$ & Bio-degradable within 3 years \\
\hline $\begin{array}{l}\text { Hazardous } \\
\text { decomposition } \\
\text { or by-product }\end{array}$ & None known & None known & None known \\
\hline
\end{tabular}

Source: Terawet Cooperation (2000); Managecraft (2001)

The soil samples were air-dried to about $20 \%\left(\mathrm{v} \mathrm{v}^{-1}\right)$ moisture content, pounded and passed through a 2-mm sieve. Sixteen identical, conical shaped, plastic buckets were filled with $8.5 \mathrm{~kg}$ of the soil samples. The buckets have a height of $0.20 \mathrm{~m}$, a base and top diameters of $0.21 \mathrm{~m}$ and $0.25 \mathrm{~m}$, respectively, and perforated at the bottom to facilitate drainage. The buckets were placed on a raised platform. A polyethylene-tarpaulin was provided as an overhead cover for the pots in an event of rains. This was to allow for careful control of soil moisture in the pots. The recommended rates of Terawet, Teraflow and Coco-Peat were applied to the soils in the pots (Table 2), and the pots watered initially to field capacity.

An improved maize variety, Obatanpa, was sown at a seeding rate of two seeds per pot. Soil moisture content was measured by both the non-destructive method with a ThetaProbe and by weighing the pots with the contents on a scale daily to determine the amount of water lost. Moisture stress was imposed on the pots by preventing any form of water into the pots, but allowing the pots to loose water by evapotranspiration for 5 consecutive days. The pots were re-saturated and another set of daily soil moisture readings for 5 days taken for two more consecutive times. The test crop was allowed to grow to its mid-stage ( 45 days), then harvested, ovendried at $60^{\circ} \mathrm{C}$ to a constant weight for above-soil level biomass determination. 
West Africa Journal of Applied Ecology (WAJAE) -ISSN: 0855-4307

Volume 9 (Jan - Jun 2006)

www.wajae.org

Water retention

Results and discussion

The effect of polymeric absorbents on soil moisture retention is presented in figure 1 with standard error bars. In general, the water retention of Terawet and Coco-Peat treated soils were similar but significantly higher ( $<<$ 0.001) than both Teraflow and the control treated soils, which were also similar. These results confirm previous observation that polymeric absorbents retain water that would otherwise have been lost by evaporation or percolation (Ouchi et al., 1989; De Boodt, 1990). Teraflow treated soils showed much lower retention than expected, and this might be due to leaching of this liquid polymeric absorbent. 
West Africa Journal of Applied Ecology (WAJAE) -ISSN: 0855-4307 Volume 9 (Jan - Jun 2006)

www.wajae.org

a) Akroso Series

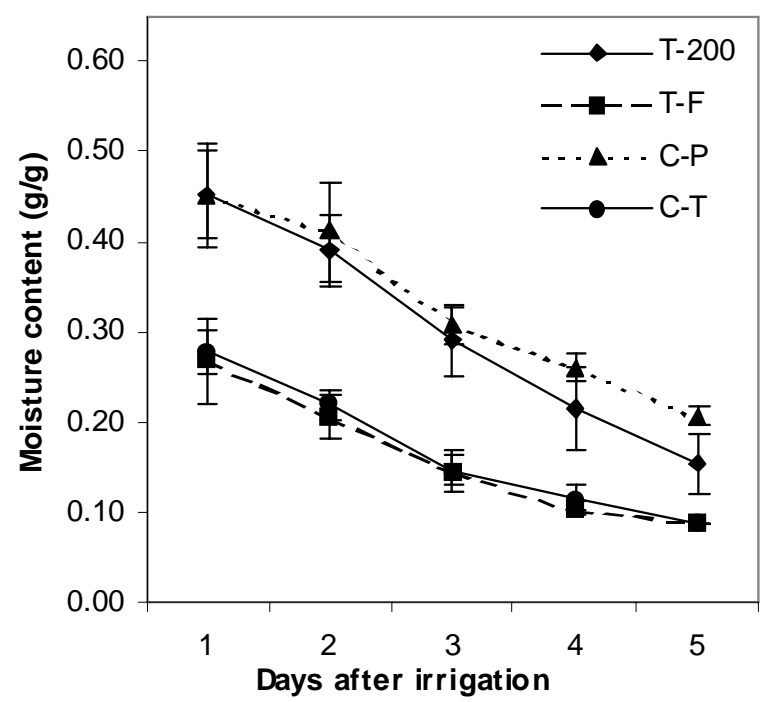

c) Amo Se ries

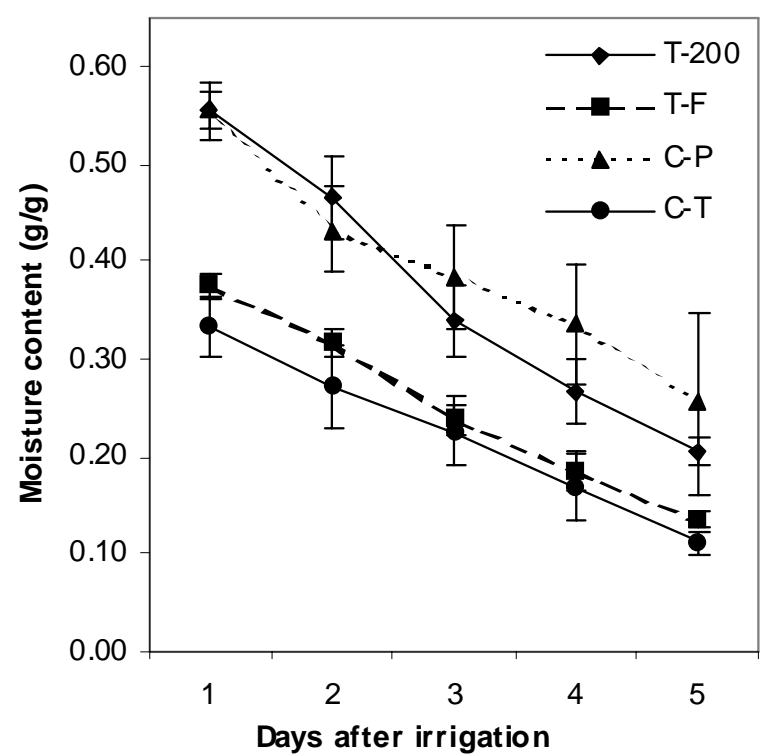

b) Akuse Series

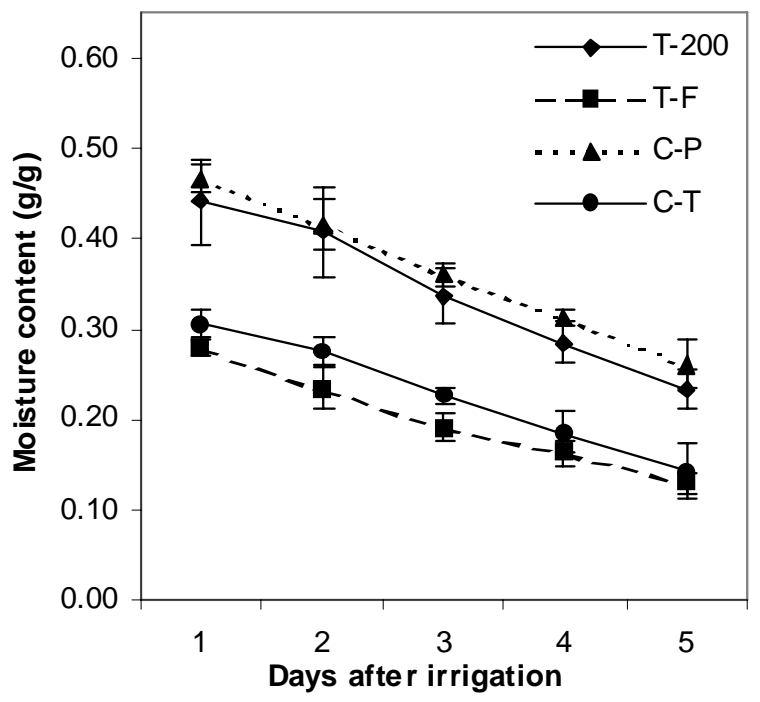

d) Hake Series

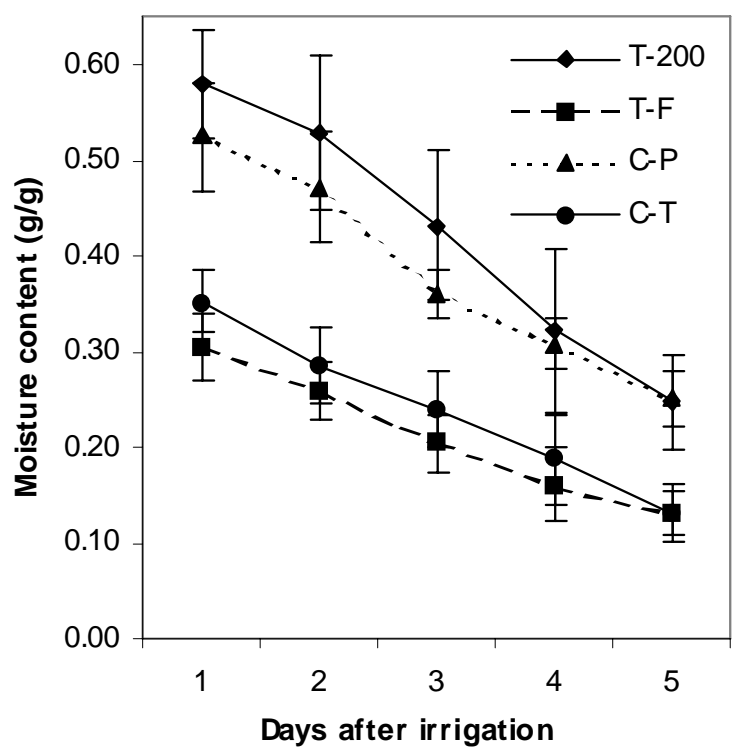

e) Oyarifa Series

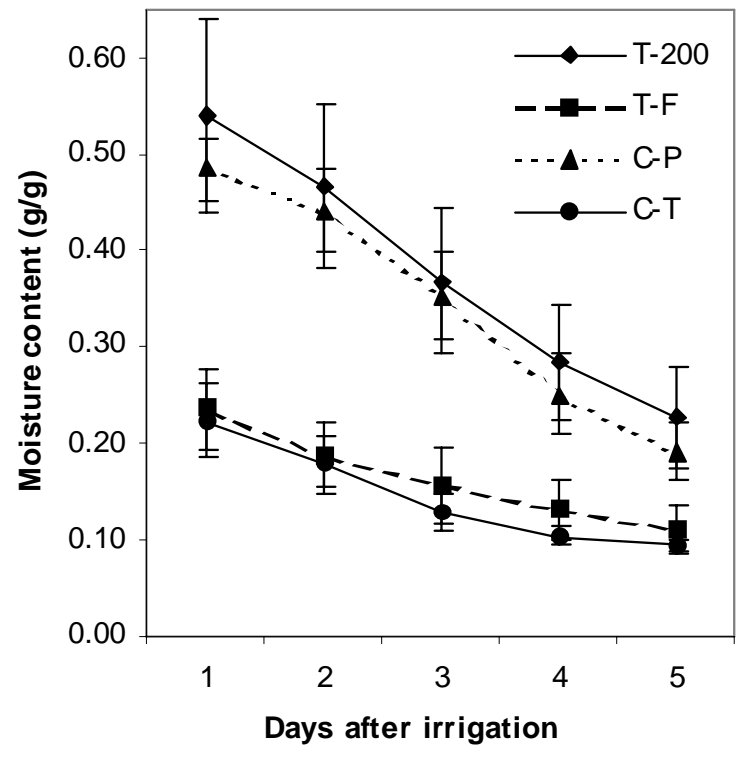

Volume 9 (Jan - Jun 2006) 


\section{West Africa Journal of Applied Ecology (WAJAE) -ISSN: 0855-4307 \\ Volume 9 (Jan - Jun 2006) \\ www.wajae.org}

Fig. 1. Water retention of polymeric absorbents on some Ghanaian soils

The influences of the natural and synthetic absorbents on Akroso series are shown in Fig. 1(a). Both T-200 and C-P amended Akroso series held water at moisture level of $45 \%\left(\mathrm{~g} \mathrm{~g}^{-1}\right)$, about $61 \%$ higher than the control treatment, which is the same as T-F treatment, after the first day of irrigation. This gradually decreased to moisture levels of $15 \%\left(\mathrm{~g} \mathrm{~g}^{-1}\right)$ and $21 \%\left(\mathrm{~g} \mathrm{~g}^{-1}\right)$ for T-200 and C-P respectively after the fifth day of irrigation, corresponding to moisture levels of $66 \%$ and $133 \%$ higher than both the control and T-F. This shows that, the introduced soil conditioners promoted wide soil moisture ranges within the volume of soil. Evidence provided by Ouchi et al. (1989) indicated that the withheld water is almost completely available to plants on continuous basis. De Boodt (1990) showed that this water is subjected not only to gravity by promoting vertical downward movement, but also to lateral suction leading to reduction in irrigation.

Akuse series, with its characteristic montmorilonitic, sandy to silty clays nature (Table 1), showed similar trends like the Akroso series (Fig. 1(b)). Treating this soil with polymeric absorbents improved its water retention. The water retention of this soil was in the order C-P > T-200 > C-T > T-F. Terawet (T-200) and C-P treated Akuse soils, held water at moisture levels of $44 \%\left(\mathrm{~g} \mathrm{~g}^{-1}\right)$ and $47 \%\left(\mathrm{~g} \mathrm{~g}^{-1}\right)$, respectively. This is equivalent to the polymeric treated soils (T-200 and C-P) holding 47\% and 57\% higher water than the control treatment respectively after the first day of irrigation. After the fifth day of irrigation, these dropped to $23 \%\left(\mathrm{~g} \mathrm{~g}^{-1}\right.$ ) and 26\% ( $\mathrm{g} \mathrm{g}^{-1}$ ) for T-200 and C-P respectively, corresponding to a moisture level of $64 \%$ and $86 \%$ higher than the control. Dehgan et al. (1994) observed that, such gradual restricted movement of water, by amending the soils with hydrogels, could result in reduced runoff and leaching of soil nutrients.

For Amo series, T-200 retained more water than C-P within the first two and half days after irrigation, but changes after this point with T-200 retaining lesser water than C-P. Both T-200 and C-P retained significantly more water than T-F and the control treatment (Fig. 1(c)). For Hake series, the order of the response of the treatments to soil water retention were in the order T-200 > C-P > C-T > T-F (Fig. 1(d)). It is important to note that even these moderately well drained soils were able to retain water, as much as, $24 \%\left(\mathrm{~g} \mathrm{~g}^{-1}\right)$ or about $100 \%$ more than the control, after the fifth day of irrigation with the exception of T-F, resulting in the cutting down of irrigation water.

The water retention of the polymeric absorbents on Oyarifa Series is shown in Fig. 1(e). Given the sandy nature of Oyarifa series T-200, C-P and T-F treated soil held as much as $54 \%\left(\mathrm{~g} \mathrm{~g}^{-1}\right), 49 \%\left(\mathrm{~g} \mathrm{~g}^{-1}\right)$ and $24 \%\left(\mathrm{~g} \mathrm{~g}^{-1}\right)$ of moisture respectively, equivalent to $146 \%, 123 \%$ and $10 \%$ respec-tively, higher than C-T after the first day of irrigation. These gradually decreased to a moisture level of 156\%, $111 \%$ and $22 \%$ more than the control, after the fifth day of irrigation.

\section{Dry matter yield}

The effects of the treatments on biomass production are presented in Fig. 2, with standard error bars. Biomass production on T-200 and C-P treated soils were similar but significantly $(\mathrm{p}<0.001)$ higher than those for both T-F and the C-T treated soils, which were also similar. Dry matter yields of 5.4, 5.2, $4.5 \mathrm{t} \mathrm{ha}^{-1}$ on T-200, C-P and T-F treated soils, respectively, on Akroso series, were $36 \%, 31 \%, 5 \%$, respectively, more than the control treatment, again demonstrating the order of efficacy of the polymeric absorbents. On Akuse series, even though T-200 and T-F gave higher dry matter yields than the control, the differences were not significant, only C-P treatment gave significantly higher dry matter yield than the control, suggesting that the recommended rates for T-200 and T-F may have to be augmented on Akuse series. 


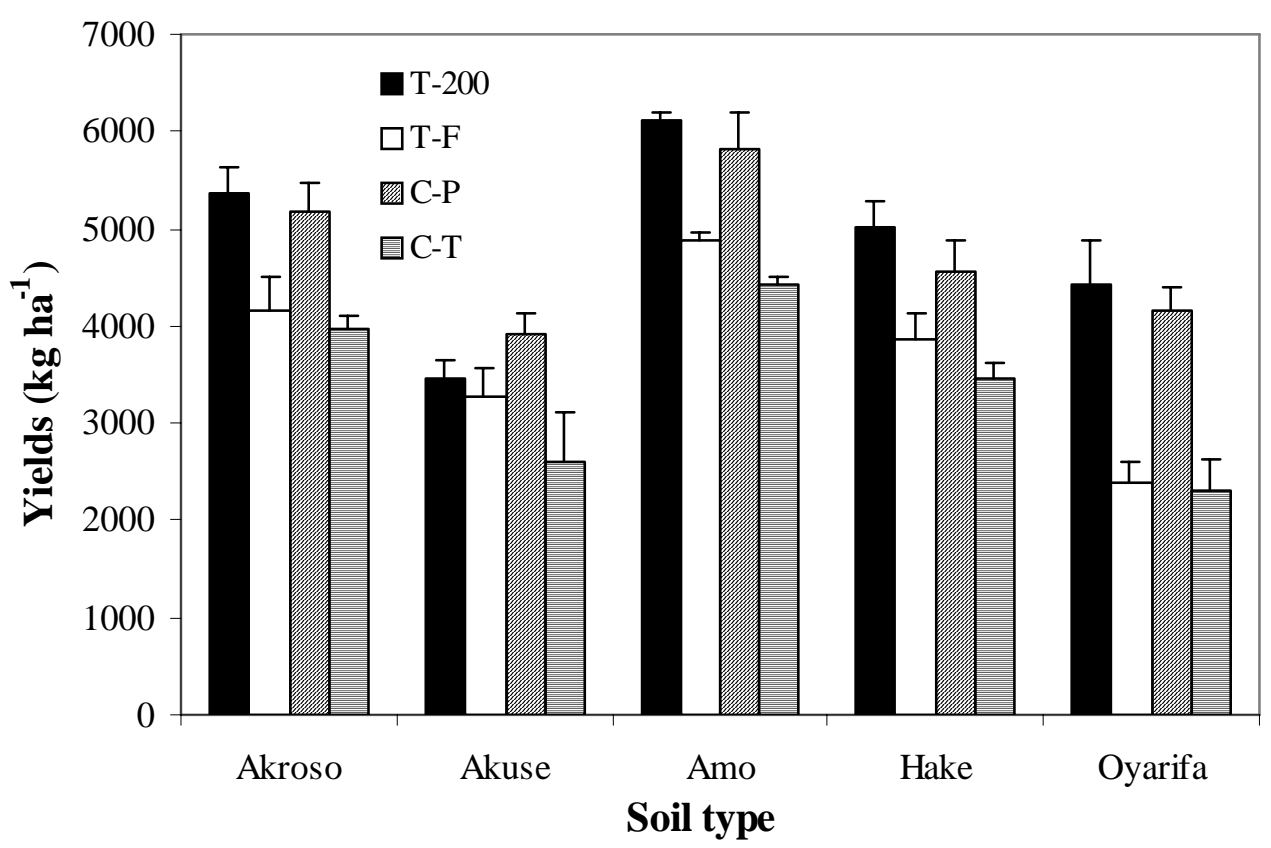

Fig. 2. Dry matter yields of test crop $\left(\mathrm{kg} \mathrm{ha}^{-1}\right)$

However, on the silty clay Amo and Hake series, the dry matter production were very high. On Amo series, the dry matter yields of 6.1, 5.8 and $4.9 \mathrm{t} \mathrm{ha}^{-1}$ on T-200, C-P and T-F treated soils respectively, were $38 \%$, 31\%, $10 \%$ more than the control treatment respectively, whilst on Hake series, the T-200, C-P and T-F treatments increased dry matter yields by $45 \%, 32 \%$ and $12 \%$, respectively.

The highest effect of the polymeric absorbents was observed on the sandy/clay/loam Oyarifa series. The treatments T-200, C-P and T-F increased yields by $92 \%, 81 \%$ and $4 \%$ over the control treatment respectively. The trend of the results confirmed the field results from Ouchi et al. (1990); Sweet (1994) and Terawet Cooperation (2000) that the differences in yields were due to the improved moisture retention ability of the amended soil by the polymeric absorbents.

\section{Conclusion}

The study of soil conditioners on Ghanaian soils showed that the water retention effects of Terawet and CocoPeat were similar but significantly greater than those of Teraflow and the non-amended soils. The unexpected lower retention of T-F treated soils might be due to leaching of this liquid polymeric absorbent. Biomass production of T-200 and C-P treated soils were similar but significantly higher than those for both T-F and the control treated soils, which were also similar.

Soil moisture retention of polymeric treated Akroso and Akuse series showed similar trend. However, on Akuse series, even though T-200 and T-F treatments produced more dry matter yields than the control, the differences were not significant, suggesting further investigation on the recommended rates for T-200 and T-F on this soil series. The moderately well drained Amo and Hake series, when amended with T-200 and C-P, were able to retain water by as much as $100 \%$ more than the control after the fifth day of irrigation. The highest effects of the polymeric absorbents were observed on the sandy/clay/loam Oyarifa series.

The management of waste plastic products in the Ghanaian environment is an alarming problem. These materials can be recycled to produce polymeric absorbents for use in crop production. Research in this regard is therefore highly recommended.

\section{Acknowledgement}




\section{West Africa Journal of Applied Ecology (WAJAE) -ISSN: 0855-4307 \\ Volume 9 (Jan - Jun 2006) \\ www.wajae.org}

The authors are grateful to Managecraft (Ghana) Limited, Terawet (Ghana) Limited and Dr John Peter Abt of Terawet Corpora-tion, San Diego, California, for their assist-ance in the experiments. Special apprecia-tion also goes to the Staff of the Agricultural Research Centre, Kpong, University of Ghana, for assistance in carrying out the experiments.

\section{References}

Azzam R. A. I. (1980). Agricultural polymers, Polycrylamide preparation, application and prospects in soil conditioning. Comm. Soil Sci. Pl. Anal. 11: 767-834.

Bouranis D. L., Theodoropoulus A. G. and Drossopooulus J. B. (1995). Designing synthetic polymers as soil conditioners. Comman. Soil Sci. Pl. Anal. 26: 1455-1480.

Bowman D. C., Evens R. Y. and Paul J. L. (1990). Fertilizer salts reduce hydration of polyacrylamide gels and affect physical properties of gel-amended container media. J. Am. Soc. Hort. Sci. 115: 382-386.

Dehgan B., Yeager T. M. and Almira F. C. (1994). Photinia and Podocarpus growth response to a hydrophilic polymer-amended medium. Hort. Sci. 29: 641-646

De Boodt M. (1975). Use of soil conditioners around the world. In Soil Conditioners. (B. A. Stewart, M. Stelly, R. C. Dinauer and J. M. Padrutt, ed.), pp. 1-12. Special Publ. Series, Madison, SSSA Soil Science Society of America Inc.

De Boodt M. (1990). Application of polymeric substances as physical soil conditioners. In Soil colloids and their association in soil aggregates. (M. De Boodt et al., ed.), pp. 580-592. Planum Publishing Corporation, London, New York.

Hillel D. (1980). Fundamentals of soil physics, pp. 113-117. Academic Press, New York.

Johnson M. S. and Leah R. T. (1990). Effects of superabsorbent polyacrylamide on efficacy of water use by crop seedlings. J. Sci. Fd Agric. 52: 431-434.

Managecraft (2001). Results of analysis of coconut husk fibre or Coco-Peat. Managecraft (GH) Ltd., Box 207, Takoradi, Ghana.

Ouchi S., Nishikawa A. and Fujita F. (1989). Soil-improving effect of a super-water-absorbent polymer. I. Total volume, three-phase distribution, and available water of super-water-absorbent polymer mixed soils. Jap. J. Soil Sci. Pl. Nutr. 60: 15-21.

Ouchi S., Nishikawa A. and Kameda E. (1990). Soil-improving effect of a super-water-absorbent polymer. II. Evaporation, leaching of salts and growth of vegetables. Jap. J. Soil Sci. Pl. Nutr. 61: 606-613.

Sweet K. (1994). Polymers in horticulture: Easy to use hydrogels can save Florida growers significant amounts of water, fertilizer, and ultimately, money. Florida Grower's Ornamental Outlook 3: 23.

Terawet Corporation (2000). http://www.terawet. com. The Terawet Corporation. 10387 Friars Road, San Diego, California,

Wallace A, and Nelson S. D. (1986). Foreword (special issue on soil conditioners) Soil Sci. 141: 311-312. 